\title{
Nursery I: The effect of stocking density on the performance of glass eels, Anguilla bicolor in the biofloc system
}

\author{
Purnama Sukardi ${ }^{1}$, Norman Ari Prayogo ${ }^{3}$, Tjahyo Winanto ${ }^{2}$, Asrul Sahri Siregar ${ }^{3}$, Taufan \\ Harisam $^{2}$ \\ ${ }^{1}$ Department of Aquaculture, Universitas Jenderal Soedirman, Indonesia \\ ${ }^{2}$ Department of Marine Science, Universitas Jenderal Soedirman, Indonesia \\ ${ }^{3}$ Department of Water Resource Management, Universitas Jenderal Soedirman.
}

\begin{abstract}
Glass eels of Anguilla bicolor is an expensive and still abundant commodity in Laguna Segara Anakan, Central Java, Indonesia. However, the growth of glass eels to elver is still a problem because of high mortality in nursery I and II. The objective of the study was to evaluate the result of stocking density on the performance of glass eels in the biofloc system during nursery I. Glass eels were stocked at densities of 54.95, 109.89 and $164.84 \mathrm{fish} / \mathrm{m}^{3}$, respectively, with three replicate ponds for each density. Eels were fed a formulated pasta-diet containing $40 \%$ crude protein and , $4 \%$ crude lipid, $5 \%$ crude fiber, $11.5 \%$ ash and $12 \%$ moisture, respectively. The water quality were maintained at levels of for fish culture througout the experiements: water temperature was $27.1^{\circ} \mathrm{C}$ (ranged from 26.3 to $\left.28.2^{\circ} \mathrm{C}\right), \mathrm{pH}(7.6$, ranged from 6.8 to 7.8$)$ and $\mathrm{DO}\left(7.2 \mathrm{mg} . \mathrm{L}^{-1}\right.$, ranged 6.9 to $\left.7.5 \mathrm{mg} . \mathrm{L}^{-1}\right)$. The results showed that the stocking density did not significantly affect the final weight, weight gain, AGR, SGR, FCR and survival, however this had a significant effect on the yield. The biofloc system was suitable for raising glass eels.
\end{abstract}

\section{Introduction}

Eels, Anguilla bicolor, Gouramy, Osphronemus gouramy, Tawes, Barbonymus goniono, and Nilem, Osteochilus hasselti have high economic value, and favored by consumers in Indonesia(23,24,25). Eels, Anguilla sp. is one of a high-priced export commodities, glass eels are still abundant, there is a ban on export glass eel, it could be stunting, and many investors are interested, but the availability of elver for growth up to the size of consumption the number is still not fulfilled $[1,2,3]$. In general, cultivation stage of eels in Java are nursery 1, 2 and then growth-out stage. Nursery 1, rearing of glass eel weighing between $0.1 \mathrm{~g}$ to elver weighing $1.5-2 \mathrm{~g}$ within 2-3 months. Nursery 2, rearing of elver weighing between 1.5-2 $\mathrm{g}$ to fingerling weighing 10-15 $\mathrm{g}$ within 2-3 months. Growth-out stage, fingerling size eels weighing $10-15 \mathrm{~g}$ reared up to $250-500 \mathrm{~g}$ (consumption size) within 5-7 months $[1,2]$. 
${ }^{1}$ Corresponding author: purnamas@unsoed.ac.id; purnamaskd@gmail.com

There were at least six species including Anguilla marmorata, A. celebensis, A. ancentralis, A. borneensis, A. bicolor bicolor and A. bicolor pacifica in Indonesian waters [4,5]. Drastic decline of eel populations in Japan, Korea, China and Taiwan, even in Japan eel is included indangered category $[1,6]$. This status becomes an opportunity for Indonesia to be able to increase production and export.

Biofloc technology is an environment-friendly aquaculture system which is considered as a sustainable approach system for future aquatic organism production $[7,8,9]$. The system is based on a live microbial which beneficially affects the host animal by improving its microbial balance [10]. The role of microorganisms is increasing culture feasibility by reducing FCR and depreciating feed cost $[8,9,11]$. Thus, high stocking density can be applied in this system that is biologically safe [12].

In aquaculture, fish stocking density directly affects water quality, behavioral, health, feeding, growth, survival and yield. Increased density leads to stress that causes increased use of energy and feed and reduces growth $[13,14]$. Optimum stocking densities required to be discovered for each species to modify efficient management and to maximize production and profitability [15]. The present study was to evaluate the result of stocking density on the performance of glass eels in the biofloc system during nursery I.

\section{Materials and Methods}

Glass eels were obtain from fisherman and were transported to $5000 \mathrm{~L}$ indoor tank in Aquaculture Laboratory, Faculty of Fisheries and Marine Science, for two days. They were randomly selected, counted and stocked into $1815 \mathrm{~L} \approx 1.82 \mathrm{~m}^{3}$ cylinder plastic pond $\{(3.14) \times(85 \times 85) \times(80)\}$, each tank contained 100, 200 and 300 fish, respectively (equivalent to $54.95,109.89$ and $164.84 \mathrm{fish} / \mathrm{m}^{3}$ ), respectively) with three replicate ponds for each density. Pond frames were made of steel covered with a plastic HDPE $(300 \mu \mathrm{m})$. Glass eels were reared for 60 days and fed four times a day with a pasta feed with $40 \%$ crude protein, crude lipid, crude fiber, ash and moisture $(40 \%, 4 \%, 5 \%, 11.5 \%$ and $12 \%$, respectively). Fish were fed at rates of $3 \%$ body weight/day until termination. The pasta were applied to fish twice daily at 07:00 $\mathrm{h}$ and 16:00 $\mathrm{h}$.

\subsection{Water quality}

Temperature and dissolved oxygen were monitored twice daily at 08:00 and 17:00 $\mathrm{h}$ with a digital oxygen-meter (YSI 55, Yellow Springs, OH, USA). The $\mathrm{pH}$ was measured daily at 12:00 using a digital $\mathrm{pH}$ meter (Hanna HI98128 pH meter). $\mathrm{CaCO} 3$ added when the $\mathrm{pH}$ drops below 7. The theoretical adding quantity of carbohydrate sources calculated according to Avnimelech[16]. In this study, molasses as carbohydrate sources were set at level of $25 \%$ of the theoretical quantity. Molasses were mixed well and spread out to the water tank in the morning. Fish were harvested after 60 days and absolute growth rate (AGR), specific growth rate (SGR), survival rate (SR), feed conversion ratio (FCR) and yield were calculated using the following equations: AGR $=\mathrm{g} /$ fish/day; SGR $(\% /$ day $)=\ln$ final weight $-\ln$ initial weight/ days $\times 100 ;$ SR $(\%)=100 \times$ (final fish count/initial fish count), FCR = total dry weight of feed offered/total fish wet weight gained, Yield (heads $\left./ \mathrm{m}^{3}\right)=$ total fish (heads)/volume of fish- pond $\left(\mathrm{m}^{-3}\right)$.

\subsection{Statistical analysis}

One way analysis of variants (ANOVA) by the SPSS (version 14) statistical package used to compare growth, survival, yield, and efficiency parameters. The ANOVA followed 
by Tukey's multiple range tests to identify differences among experimental groups. Prior to analysis, arcsine-transformation applied to the percentage.

\section{Results and Discussion}

\subsection{Water quality parameters}

During the study, parameters of water quality were maintained within the tolerance range for most freshwater species used in aquaculture. The water characteristics did not present any significant difference among fish densities. Average water temperature was $27.1^{\circ} \mathrm{C}$ (ranged from 26.3 to $28.2^{\circ} \mathrm{C}$ ), $\mathrm{pH}$ (7.6, ranged from 6.8 to 7.8 ) and $\mathrm{DO}\left(7.2 \mathrm{mg} . \mathrm{L}^{-1}\right.$, ranged 6.9 to $\left.7.5 \mathrm{mg} \cdot \mathrm{L}^{-1}\right)$.

Tabel 1. Performance of glass eels, Anguilla bicolor, in the BFT at the end of experiment

\begin{tabular}{llll}
\hline Parameter & $\begin{array}{l}\text { Stocking } \\
\text { densities }\end{array}$ & $\begin{array}{l}\text { Stocking } \\
\text { densities }\end{array}$ & $\begin{array}{l}\text { Stocking } \\
\text { densities }\end{array}$ \\
& $(54.95 \mathrm{fish} / \mathrm{m} 3)$ & $(109.89 \mathrm{fish} / \mathrm{m} 3)$ & $(164.84 \mathrm{fish} / \mathrm{m} 3)$
\end{tabular}

\begin{tabular}{llll}
\hline Initial weight $(\mathrm{g})$ & $0.09 \pm 0.01^{\mathrm{a}}$ & $0.09 \pm 0.01^{\mathrm{a}}$ & $0.09 \pm 0.01^{\mathrm{a}}$ \\
\hline Final weight $(\mathrm{g})$ & $1.41 \pm 0.13^{\mathrm{a}}$ & $1.42 \pm 0.12^{\mathrm{a}}$ & $1.41 \pm 0.12^{\mathrm{a}}$ \\
\hline Weight gain $(\mathrm{g})$ & $1.33 \pm 0.13^{\mathrm{a}}$ & $1.34 \pm 0.11^{\mathrm{a}}$ & $1.32 \pm 0.12^{\mathrm{a}}$ \\
\hline AGR (g/day) & $0.022 \pm 0.002^{\mathrm{a}}$ & $0.022 \pm 0.002^{\mathrm{a}}$ & $0.022 \pm 0.002^{\mathrm{a}}$ \\
\hline SGR (\%/day) & $4.62 \pm 0.23^{\mathrm{a}}$ & $4.62 \pm 0.21^{\mathrm{a}}$ & $4.60 \pm 0.21^{\mathrm{a}}$ \\
\hline FCR & $1.26 \pm 0.01^{\mathrm{a}}$ & $1.24 \pm 0.02^{\mathrm{a}}$ & $1.26 \pm 0.04^{\mathrm{a}}$ \\
\hline Survival (\%) & $51.33 \pm 2.52^{\mathrm{a}}$ & $51.33 \pm 1.53^{\mathrm{a}}$ & $50.33 \pm 1.53^{\mathrm{a}}$ \\
\hline $\begin{array}{l}\text { Yield } \\
\text { (heads/m3) }\end{array}$ & $32.3 \pm 1.6^{\mathrm{a}}$ & $64.7 \pm 1.9^{\mathrm{b}}$ & $92.6 \pm 1.9^{\mathrm{c}}$ \\
\hline
\end{tabular}

Means $( \pm \mathrm{SD})$ of the initial and final weight $(\mathrm{g})$, weight gain $(\mathrm{g})$, AGR $(\mathrm{g})$, FCR, survival and yield $(\mathrm{kg} \mathrm{m}-3)$. Means within a row followed by different superscript letters were significantly different $(\mathrm{P}<0.05)$

Our finding showed that stocking density was not significantly influenced final weight, weight gain, AGR, SGR, FCR and survival, it was significantly influenced production. Glass eels growth was not significantly influenced by density. Mean final weight were 1.41, $1.42,1.41 \mathrm{~g}$ and mean weight gained were $1.33,1.34,1.32 \mathrm{~g}$ at $54.95,109.89$ and 164.84 fish $/ \mathrm{m} 3$, respectively, which were in agreement with Björnsson and Ólafsdóttir [17] study in juvenile cod (Gandus morhua L.). AGR and SGR was not significantly influenced $(\mathrm{P}<0.05)$ by density. Our study showed that survival of glass eels was not significantly affected by stocking density. Average of survival rates were 51.33, 51.33, 50.33\% at 54.95, 109.89 and 164.84 fish/m3, respectively. Similarly, stocking density of fingerlings of silver perch, Bidyanus bidyanus, stocked at 100 or $200 \mathrm{fish} / \mathrm{m} 3$ was not influenced survival. Several studies have also shown that the density have not significantly effect on survival of rainbow trout, Oncorhynchus mykiss [18], tambaqui, Colossoma macropomum [19] and Oreochromis niloticus [20]. Conversely with these study, it found in the endangered teleost species piabanha, Brycon insignis was higher survival at low stocking density [13]. In this 
experiment found that higher productivity for glass eels, Anguila bicolor at higher stocking density. It shown that a productivity of 92.6 heads $/ \mathrm{m} 3$ was obtained at a stocking density of $164.84 \mathrm{fish} / \mathrm{m} 3$. High density in the pond also obtained high yields on the matrinxã larvae, Cephalus characidae [21] and it was directly proportional to production, which could be used to increase profits [22]. The yield of this study could probably be improved with the addition of glass eel density and better seed quality.

\section{Conclusions}

The data obtained suggest that stocking density was not significantly influenced final weight, weight gain, AGR, SGR, FCR and survival, however it was significantly influenced yield. Further studies could be conducted to determine optimal feeding rate of glass eels in the biofloc system. The continuation of the study with glass eels is important to provide data and to optimize the production, as well as to improve the management of glass eels in the biofloc system.

We are indebted to the Directorate General of Higher Education, Ministry of Research, Technology and Higher Education of the Republic of Indonesia for the financial support of this work, which was made available through Hibah Strategis Nasional (STRANAS)

\section{Reference}

1 Murjani, M. Discussion forum of eel aquaculture national III. (Yogyakarta, September, 24, 2014)

2 Sukardi, P., Winanto, T. and Harisman, T. Proceeding International Conference of Aquaculture Indonesia (ICAI). (2012)

3 Sukardi, P., Hana, Prayogo,N.A., Sulistyo,I.,Soedibyo, P.H.T., Harisam,T.,Winanto,T.. Acta Scientiarum Animal Sciences. 40, (2018)

4 Affandi, R. Jurnal lktiologi Indonesia. 5, 77-81 (2005)

5 Shen, K.N. and Tseng, W.N. Zoological Studies. 46, 441-453 (2007)

6 Nakai, T. Discussion forum of eel aquaculture national III. (Yogyakarta, 24, 2014)

7 Hargreaves, J.A. Southern Regional Aquaculture Center (SRAC) (2013)

8 Schveitzer, R., R. Arantes, M.F. Baloi, P.F.S. Costodio, L.V.Arana, W.Q. Seiffert, E.R. Andreatta. Aquacultural Engineering. 54, 93- 103 (2013)

9 Xu, W.J., L.Q. Pan, and D.H. Zhao. Aquaculture. 147-153 (2012)

10 Perez-Sanchez,T., Ruiz-Zarzuela, I., de Blas,I. and Balcazar,JL. Reviews in Aquaculture. 5, 1-14 (2013)

11Martínez-Córdova, L. R., M. Martínez-Porchas, M.G.C. Emerenciano, A. Miranda-Baeza, T. Gollas-Galván. Critical Reviews in Biotechnology. 37, 1-9 (2017)

12 Goodall, J.D., Wade, N.M., Merritt, D.J., Sellars, M.J., Salee, K., Coman, G.J. Aquaculture. 450, 206-212, 2016)

13 Tolussi, C.E., A.W.S. Hilsdorf, D. Caneppele, R.G.Moreira. Aquaculture. 310, 221-228 (2010)

14 Schram, E., J. W. Van Der Heul, A. Kamstra, M. C J Verdegem. Aquaculture. 252, 339-347 (2006)

15 Huertas, M., J. Cerda. Biological Bulletin. 211, 286-296 (2006)

16 Avnimelech, Y. Aquaculture . 176, 227-235 (1999)

17 Björnsson, B., and S.R., Ólafsdóttir. ICES Journal of Marine Science. 63, 326-334 (2006)

18 Wallat, G.K., Tiu, L.G., Rapp, J.D., Moore, R. Journal of Applied Aquaculture. 15, 73-82 (2004) 
19 Gomes, L, E. Chagas, H. Martins-Junior, R. Roubach, E.A. Ono, J.N. De Paula Lourenço. Aquaculture. 253, 374-384 (2006)

20 Gibtan, A., A. Getahun and S. Mengistou. Aquaculture Research. 39, 1450-1460. (2008)

21 Gomes, L. C., B. Baldisserotto and J.A. Senhorini. Aquaculture. 183, 73-81(2000)

22 Rahman, M., M. Islam, G.C. Halder and M. Tanaka. Aquaculture Research. 37, (2006)

23. N.A Prayogo, g.e. wijayanti, murwantoko, m. Kawaichi and p. Astuti. 8(6) : 591-597. (2012)

24. N.A Prayogo, G.E. Wijayanti, I. Sulistyo, P. Sukardi. Biodiversitas. 17, 523-530 (2016)

25. N.A. Prayogo, A. Siregar, P. Sukardi. Turkish journal fishery and aquatic science. 16, 1003-1009 (2016) 